\title{
Nitrogen, potassium, calcium and sulfur omission in grass Convert
}

\author{
Rafaela Pereira Miranda', Marizane Pietroski²*, Fabiano Bernardo Matos³, \\ Getulio Freitas Seben Junior', Gustavo Caione'
}

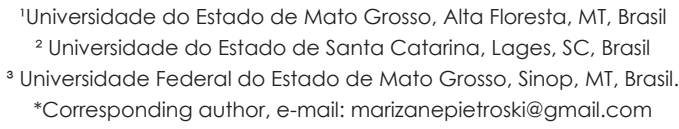

\begin{abstract}
Intensive use of Brazilian pastures without the maintenance of soil fertility has decreased their productivity and favoring the onset of symptoms of nutritional deficiency. The objective of this study was to evaluate the effect of nitrogen, potassium, calcium and sulfur omission in symptomatology, growth and dry mass accumulation in grass Convert. The experiment was conducted in a greenhouse with a completely randomized design, with five treatments and four replications. The treatments were: full nutrient solution, nitrogen omission ( $N$ ), potassium omission (K), calcium omission (-Ca) and sulfur omission (S). The variables were the number of tillers, leaf number, root size, shoot height, characterization of symptoms of deficiency and shoot and root dry mass accumulation. The data were submitted to the $\mathrm{F}$ test by analysis of variance and comparison of means by Tukey's test $(p<0.05)$. The omission of $N, K, C a$ and $S$ limited the development of Convert grass compared to the full nutrient solution treatment, reducing the number of leaves, tillers, height, root size and dry mass production. The nutrient omission modified forage morphology, showing visual symptoms of deficiency of each nutrient evaluated. The decreasing order of onset of symptoms was $\mathrm{N}, \mathrm{Ca}, \mathrm{S}$ and $\mathrm{K}$.
\end{abstract}

Keywords: nutritional deficiency, macronutrients, symptomatology, nutrient solution, Urochloa.

\section{Introduction}

Livestock farming is one of the main productive activities of the Brazilian agribusiness, and grass-based feeding is the main diet for dairy and beef cattle (Ferraz \& Felício, 2010). Among the grasses used for animal feed, the Convert hybrid grass can be highlighted, which is a grass that easily adapts to tropical and subtropical conditions. In addition, developed studies indicate high productive potential (10 to $27 \mathrm{t} \mathrm{ha}^{-1}$

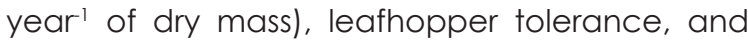
efficiency on residual fertilizers utilization (Argel et al., 2007).

Forage species are the main sources of nutrients for pasture-raised beef cattle. In soils with low fertility their productivity decreases, thus, fertilization practices are required for its implantation (Duarte et al., 2015). If the concentration of a certain nutrient is below the level considered adequate for the plant development, the nutrient is considerate deficient for that element. This deficiency can delay the metabolic processes in which the element is involved, and also affect other processes (Epstein \& Bloom, 2006).

The symptomatology of nutritional deficiency is due to the functions performed by each nutrient. However, it is possible to have different responses between and within species, due to the genetic expression of each one and 
thus, influencing the distribution of nutrients (Prado, 2008b).

The technique of plant growing in nutrient solution has allowed advances in the knowledge of plant nutrition since it controls more adequately the composition of the solution and eliminates the heterogeneity and complexity present in the soil (Avalhães et al., 2009).

Thus, the deficiency symptoms of a specific nutrient in the plant, which shows peculiar characteristics, will have an easier foliar diagnosis by farmers and technicians, as well as the distinction of each deficiency symptom, since there are differences of symptomatology for each cultivar or species on the absence and / or in a lower amount of a specific nutrient in the field.

Therefore, the objective of this study was to evaluate the effect of the N, K, Ca and
S omission on symptomatology, growth and dry mass accumulation in the Convert grass.

\section{Materials and methods}

The experiment was carried out in a greenhouse at "Universidade do Estado de Mato Grosso" - UNEMAT, Alta Floresta campus, Mato Grosso state.

The experimental design was a completely randomized design, with five treatments and four replications. The treatments were composed of full nutrient solution ( $N, P, K$, $\mathrm{Ca}, \mathrm{Mg}, \mathrm{S}, \mathrm{B}, \mathrm{Cl}, \mathrm{Cu}, \mathrm{Fe}, \mathrm{Mn}, \mathrm{Mo}$ and $\mathrm{Zn}$ ); nitrogen omission $(-N)$; potassium omission $(-K)$; calcium omission (-Ca) and, sulfur omission (-S). The Convert grass sowing was carried out in October 2014, in a 200 cell polystyrene tray, filled with a commercial substrate (Vivatto) (Table 1).

Table 1. The chemical composition of the commercial substrate Vivatto.

\begin{tabular}{|c|c|c|c|c|c|}
\hline $\mathrm{pH}$ & $\mathrm{Ca}$ & $\mathrm{Mg}$ & $\mathrm{Na}$ & K & $P$ \\
\hline $\mathrm{H}_{2} \mathrm{O}$ & & 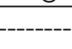 & $\lg d r$ & 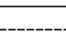 & \\
\hline 5.2 & 440 & 324 & 51 & 211 & 11 \\
\hline
\end{tabular}

At 12 days after sowing (approximately four leaves), the Convert grass seedlings were removed from the tray cells and washed, firstly with running water to make the total removal of the substrate, and then washed with deionized water to remove any contaminating element present in the running water. The seedlings were transferred to pots containing $7 \mathrm{~L}$ of Hoagland and Arnon (1950) nutrient solution in a hydroponic system.

In each pot, eight seedlings were placed, according to the methodology described by Prado and Vidal (2008) for the millet and Prado et al. (2010) for the soybean, in which two plants represent a replication. The evaluations were performed for the two plants and the mean was used, totaling four replications.

Initially, during the first six days, the nutrient solution was used with half of the usual concentration for seedling adaptation and, on the 7th day after the establishment of the experiment, the rest of the solution was added, totalizing $100 \%$ of nutrient concentration (Table 2).

During the plant growing, the nutrient solutions received constant oxygenation using air compressors (aquarium pumps). A pH meter was used to daily measure the nutrient solution in order to maintain the nutrient solution with $\mathrm{pH}$ equal to $5.9 \pm 0.1$ using a $0.1 \mathrm{~mol} \mathrm{~L}^{-1} \mathrm{HCl}$ solution. The water losses by evapotranspiration were restored by the addition of distilled and deionized water, followed by $\mathrm{pH}$ measurement and correction. At 29 days after the establishment of the experiment, the nutrient solution was renewed in order to maintain adequate levels of nutrients.

The plants were monitored daily for visual symptomatology in order to characterize the deficiency symptoms for each evaluated element. At 21, 32 and 41 days after transplanting, at which time the advanced symptoms of nutritional deficiency were expressed, tiller and leaf counts, shoot height and determination of the green color index were performed. The green color determination was performed only once using the CCM 200 chlorophyll meter (OptiSciences) in the morning period, in the central region of the first fully developed leaf of all plants. At the end of the experiment, root growth was analyzed based on the growth of the longest 
Table 2. The composition of Hoagland and Arnon (1950) nutrient solution.

\begin{tabular}{|c|c|c|c|c|c|c|}
\hline \multirow{2}{*}{$\begin{array}{l}\text { Fertilizers/Salts for stock } \\
\text { solutions }\end{array}$} & \multirow{2}{*}{$\begin{array}{l}\text { Concentration } \\
\text { of stock solution }\end{array}$} & Full & $-\mathrm{N}$ & $-K$ & $-\mathrm{Ca}$ & $-S$ \\
\hline & & \multicolumn{5}{|c|}{ Volume of stock solution per $\mathrm{L}$ of the final solution } \\
\hline & $\mathrm{g} \mathrm{L}^{-1}$ de água & ---- & - & $\mathrm{mL}$ & - & ---- \\
\hline $1-\mathrm{KH}_{2} \mathrm{PO}_{4}\left(\mathrm{MOl} \mathrm{L}^{-1}\right)$ & 136.09 & 1 & 1 & - & 1 & 1 \\
\hline $2-\mathrm{KNO}_{3}(\mathrm{Mol} \mathrm{L}-1)$ & 101.11 & 5 & - & - & 5 & 3 \\
\hline 3-Ca $\left(\mathrm{NO}_{3}\right)_{2} 5 \mathrm{H}_{2} \mathrm{O}(\mathrm{Mol} \mathrm{L}-1)$ & 236.16 & 5 & - & 5 & - & 4 \\
\hline $4-\mathrm{MgSO}_{4} \cdot 7 \mathrm{H}_{2} \mathrm{O}\left(\mathrm{MOl} \mathrm{L}^{-1}\right)$ & 247.47 & 2 & 2 & 2 & 2 & - \\
\hline $5-\mathrm{KCl}\left(\mathrm{Mol} \mathrm{L}^{-1}\right)$ & 74.56 & - & 5 & - & - & 2 \\
\hline $6-\mathrm{CaCl}_{2} 2 \mathrm{H}_{2} \mathrm{O}\left(\mathrm{Mol} \mathrm{L}^{-1}\right)$ & 147.02 & - & 5 & - & - & 1 \\
\hline $7-\mathrm{NH}_{4} \mathrm{H}_{2} \mathrm{PO}_{4}\left(\mathrm{MOl} \mathrm{L}^{-1}\right)$ & 115.31 & - & - & 1 & - & - \\
\hline $8-\mathrm{NH}_{4} \mathrm{NO}_{3}(\mathrm{Mol} \mathrm{L}-1)$ & 80.04 & - & - & 2 & 5 & - \\
\hline 9- $\left(\mathrm{NH}_{4}\right)_{2} \mathrm{SO}_{4}(\mathrm{Mol} \mathrm{L}-1)$ & 132.14 & - & - & - & - & - \\
\hline $10-\mathrm{MgNO}_{3} \cdot 6 \mathrm{H}_{2} \mathrm{O}\left(\mathrm{Mol} \mathrm{L}^{-1}\right)$ & 256.43 & - & - & - & - & 2 \\
\hline 11-Micros solution* & & 1 & 1 & 1 & 1 & 1 \\
\hline 12- Fe-EDTA solution** & 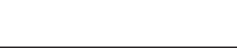 & 1 & 1 & 1 & 1 & 1 \\
\hline
\end{tabular}

root (GLR), with a 1-mm graduated scale.

The collected plants were separated into the shoot and root parts. The material was packed in paper bags and taken to a forced air oven at $65^{\circ} \mathrm{C}$ until constant weight. Subsequently, the samples were weighed to obtain the shoot and root dry mass.

The data were submitted to analysis of variance by the $\mathrm{F}$ test and the comparison of means by the Tukey test ( $P<0.05)$, using Sisvar statistical software(Ferreira, 2011).

\section{Results and discussion}

At 21 and 32 days of the establishment of the experiment, the $-\mathrm{N}$ treatment showed $\mathrm{a}$ smaller number of tillers (Table 3 ) than the full solution treatment. At the end of the experiment (41 days), it was observed that the $-\mathrm{N}$ treatment showed the smallest number of tillers. The -Ca treatment showed the number of tillers greater than the full solution treatment, this can be explained by the death of the growth regions, such as the stem apex, inducing the emission of lateral shoots in forage species (Prado, 2008b).

Table 3. Number of tillers (NT) at 21, 32 and 41 days after the establishment of the experiment and the growth of the longest root (GLR), as a function of the omission of nutrients.

\begin{tabular}{|c|c|c|c|c|}
\hline Treatment & NT at 21 days & NT at 32 days & NT at 41 days & GLR \\
\hline Full solution & $2.25 a$ & $5.75 \mathrm{ab}$ & $5.00 \mathrm{~b}$ & $30.96 \mathrm{bc}$ \\
\hline $\mathrm{N}$ & $0.25 b$ & $1.50 c$ & $1.50 \mathrm{c}$ & $54.99 a$ \\
\hline K & $1.50 \mathrm{ab}$ & $4.37 a$ & $3.50 \mathrm{~b}$ & $46.08 \mathrm{~b}$ \\
\hline $\mathrm{Ca}$ & $1.25 a b$ & $6.25 a$ & $7.25 a$ & $23.19 c$ \\
\hline S & $1.25 \mathrm{ab}$ & $4.00 \mathrm{~b}$ & $3.63 b$ & $65.13 a$ \\
\hline LSD & 1.38 & 1.96 & 2.11 & 16.21 \\
\hline F value & $5.13^{* *}$ & $17.00^{* *}$ & $19.43^{* *}$ & $21.33^{* *}$ \\
\hline CV (\%) & 48.65 & 20.60 & 23.09 & 16.84 \\
\hline
\end{tabular}

The $-\mathrm{N}$ and $-\mathrm{S}$ treatments showed a larger root length values than those found in the full solution treatment, due to these nutrients have similar functions, resulting in similar symptoms. These results agree with those found by Coelho et al. (2011) in Tagetes erecta, and by Maia et al. (2014) in Jatropha, under nutritional deficiencies.

The Ca omission affected the root growth, resulting in the death of the apical bud, leaving them looking thicker, which is associated with the initial region of deficiency, occurring in growth regions (Figure 1). The results obtained in this study were similar to those reported by Vale et al. (2011) for sugarcane and by Avalhães et al. (2009) for elephant-grass. The -K treatment did not differ statistically for the growth of the longest 
root in relation to the full solution treatment. Similar results were observed in cherry seedlings under K omission (Vieira et al., 2011).

The $-\mathrm{N}$ treatment obtained a smaller number of leaves in all evaluated periods and a lower green color index compared to the full solution treatment (Table 4). This symptom is related to the function of the nutrient, which participates directly in photosynthesis process, and is part of the structure of the plant (Prado, 2008b). Avalhães et al. (2009) observed in plants of elephant-grass under the $-\mathrm{N}$ treatment, chlorosis in the older leaves and afterward in the whole plant. The lower development of plants with $\mathrm{N}$ deficiency is related to its participation in fundamental biomolecules and the chlorosis occurs since $\mathrm{N}$ is a constituent of chlorophylls (Prado, 2008b).

Table 4. Number of leaves (NL) at 21, 32 and 41 days after the establishment of the experiment and green color index as a function of the omission of nutrients.

\begin{tabular}{|c|c|c|c|c|}
\hline Treatment & NL at 21 days & NL at 32 days & $\mathrm{NL}$ at 41 days & Green color \\
\hline Full solution & $10.13 a$ & $21.00 a$ & $29.37 a$ & $55.31 a$ \\
\hline$-N$ & $4.00 \mathrm{~b}$ & $4.13 b$ & $4.13 c$ & $20.34 d$ \\
\hline$-K$ & $8.38 a$ & $17.25^{a}$ & $18.75 b$ & $47.99 b$ \\
\hline$-\mathrm{Ca}$ & $8.50 a$ & $21.63^{a}$ & $35.50 a$ & $60.56 a$ \\
\hline$-S$ & $8.00 a$ & $14.25^{a}$ & $14.63 \mathrm{~b}$ & $38.14 \mathrm{C}$ \\
\hline LSD & 3.69 & 8.89 & 9.48 & 8.59 \\
\hline F value & $1.25^{* *}$ & $12.17^{* *}$ & $32.38^{* *}$ & $65.32^{* *}$ \\
\hline $\mathrm{CV}(\%)$ & 21.68 & 26.00 & 21.19 & 8.85 \\
\hline
\end{tabular}

Thereafter, the treatments that most limited the number of leaves were the $-S$ treatment, followed by the $-\mathrm{K}$ treatment. For the color index green, after the $-\mathrm{N}$ treatment, the most limiting treatments were $-S$ and $-K$. Similar results were found by Almeida et al. (2008) in lettuce and by Avalhães et al. (2009) in elephantgrass. Similar results were also reported by Prado and Vidal (2008) in millet and by Vale et al. (2011) in sugarcane, under omission of macronutrients, grown in nutrient solution.

The $\mathrm{Ca}$ omission resulted in the highest number of leaves at 41 days after the establishment of the experiment, with rigid foliar limb, lacerated and chlorinated leaves margin, and green color index equal to the full solution treatment (Figure 1 and 2). According to Prado et al. (2010), these symptoms are related to their function in the plant, being part of the $\mathrm{Ca}$ pectatos of the cell wall, is required for cellular mitotic elongation and division. The coloration similar to the full solution treatment is due to the accumulation of nutrients present in the chloroplasts.

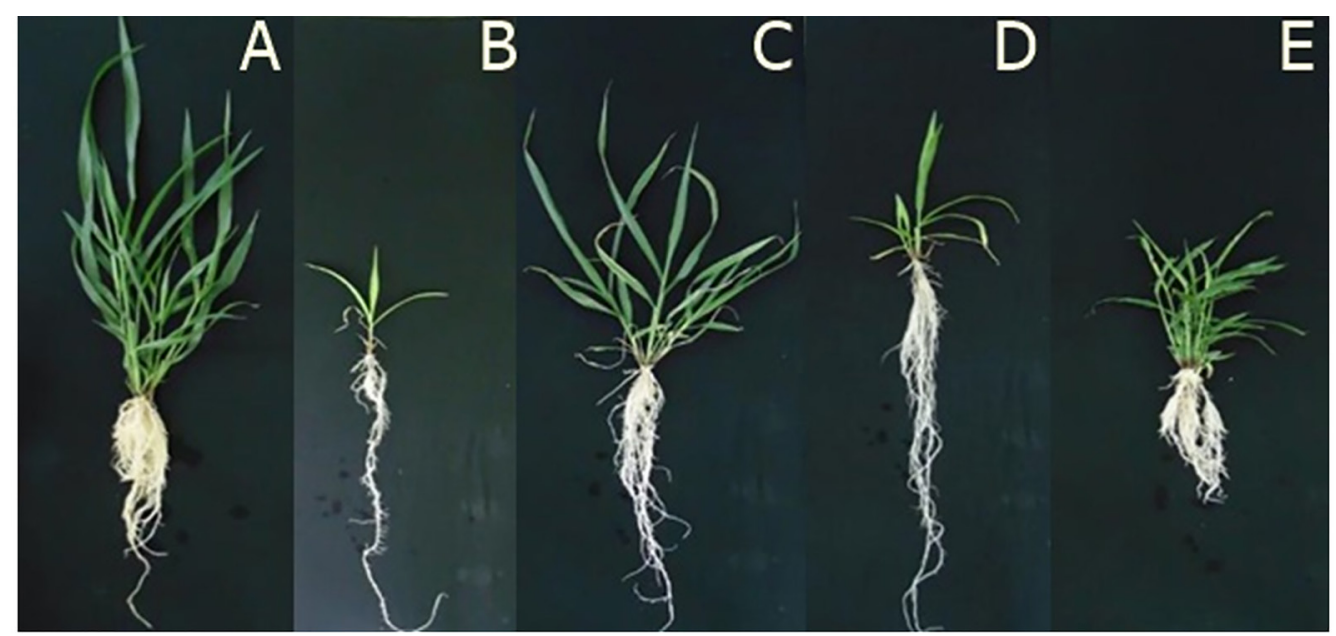

Figure 1. Pictures of root length, height, number of tillers and number of leaves in the full solution (A), N omission (B) K omission (C), S omission (D) and Ca omission (E) treatments for Convert grass. 
The $\mathrm{N}, \mathrm{Ca}$, and $\mathrm{S}$ omission treatments showed lower plant height values than the full solution treatment at the 32 and 41 days after the establishment of the experiment (Table 5). The -K treatment did not differ significantly by plant height. A similar result was found for black oats (Rozane et al., 2008). The root dry mass in the $-\mathrm{N}$, $-K$ and -Ca treatments were lower than those found in the full solution treatment. However, the -S treatment did not differ significantly for this variable.

The - $\mathrm{N}$ treatment showed the lowest shoot dry mass followed by the $-\mathrm{S}$, -Ca and -K treatments. Among the evaluated macronutrients, $\mathrm{N}$ was the one that affected the most at plant height, root and shoot dry mass accumulation(Figure 1). The order of appearance of the visual symptoms of nutritional deficiency was N, Ca, S and K.

Table 5. Plant height (PH) of Convert grass at 21, 32 and 41 days after the establishment of the experiment and root (RDM) and shoot dry mass (SDM) accumulation as a function of the omission of nutrients.

\begin{tabular}{|c|c|c|c|c|c|}
\hline Treatment & $\mathrm{PH}$ at 21 days & $\mathrm{PH}$ at 32 days & $\mathrm{PH}$ at 41 days & RDM & SDM \\
\hline Full solution & $17.88 a$ & $48.02 a$ & $61.09 a$ & $1.99 a$ & $7.46 a$ \\
\hline$-\mathrm{N}$ & $23.81 a$ & $22.01 c$ & $21.87 c$ & $0.41 \mathrm{bc}$ & $0.53 c$ \\
\hline$-K$ & $22.01 a$ & $41.35 a b$ & $49.44 a b$ & $0.76 b$ & $3.40 \mathrm{~b}$ \\
\hline$-\mathrm{Ca}$ & $24.38 a$ & $20.91 c$ & $35.93 \mathrm{bc}$ & $0.65 b$ & $3.03 b$ \\
\hline$-S$ & $21.24 a$ & $33.25 b$ & $37.05 b$ & $1.29 \mathrm{ab}$ & $2.25 \mathrm{bc}$ \\
\hline LSD & 10.19 & 9.91 & 14.80 & 0.77 & 2.11 \\
\hline F value & $1.21 \mathrm{~ns}$ & $27.32^{* *}$ & $19.20^{* *}$ & $12.65^{* *}$ & $28.05^{* *}$ \\
\hline CV (\%) & 21.34 & 13.70 & 16.49 & 34.77 & 28.99 \\
\hline
\end{tabular}

The plants under $-\mathrm{N}$ treatment showed uniform chlorosis in the older leaves, progressing to the younger leaves (Figure 1), similar results were found by Prado et al. (2011) in Tanzania grass grown in nutrient solution with the omission of macronutrients. This effect is due to their participation in the synthesis of chlorophyll and the symptom appears in the older leaves due to the redistribution of $\mathrm{N}$ to the younger leaves. In the - $\mathrm{N}$ treatment the main roots were longer greater than in the full solution treatment, however, it showed adventitious roots little developed. The lower height and lower dry mass accumulation of $\mathrm{N}$-deficient plants are due to its participation in several vital physiological processes, such as photosynthesis and respiration (Prado, 2008a).
Plants with $\mathrm{K}$ omission showed visually symptoms of marginal chlorosis and necrosis, from the tips to the base of the leaf and chlorosis from the edges to the center on the older leaves (Figure 2), such symptoms were also observed in sorghum (Fonseca et al. , 2008) and in Jatropha (Silva et al., 2009). According to Prado (2008b), necrosis is due to the presence of putrescine in leaves, a toxic substance for plants. The forage obtained lower values of the shoot and root dry mass compared to the full solution treatment. Avalhães et al. (2009) observed in elephant-grass under macronutrients omission, $K$ deficiency, affecting the shoot and root dry mass accumulation, and showed symptoms characteristic of deficiency of the respective nutrient.

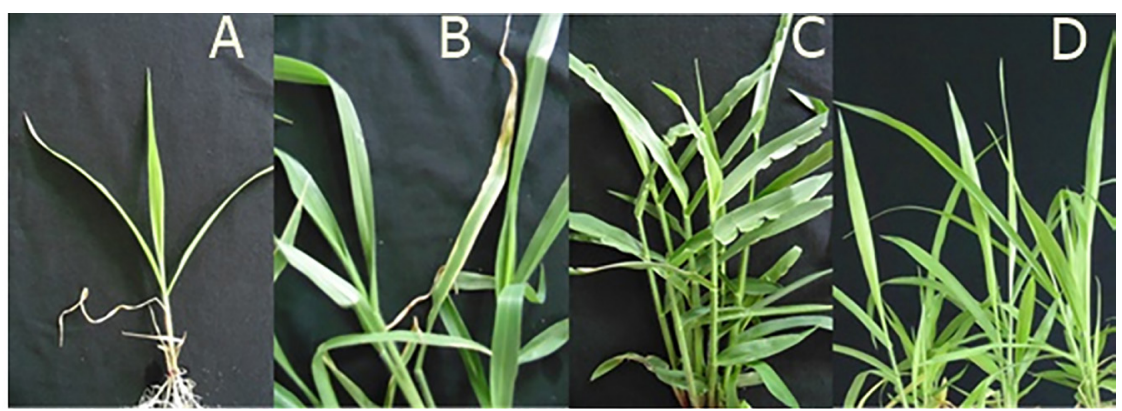

Figure 2. Picture of the characteristic symptoms of deficiency in the $-N$ treatment $(A),-K$ treatment (B), $-\mathrm{Ca}$ treatment $(C)$ and $-S$ treatment (D). 
Due to the Ca omission, the forage showed visual symptoms of deficiency with dark green color on the leaves and stems, leaves with a rigid aspect, whitish color on the edges of the younger leaves, laceration beginning at the leaf margin and ending at the central leafvein, greater number of tillers, reduction in root and shoot growth (Figure 1 and 2). According to Prado (2008b), the presence of these symptoms at the cellular level causes collapses in the cell division, causing the plant growth to stop. Since Ca has a structural function as a cementing agent, its absence causes disintegration in the middle lamella and can influence texture and firmness of the tissues.

The shoot and root dry mass accumulation in the -Ca treatment was lower than in the full solution treatment, similar to the results observed by Avalhães et al. (2009) in Tanzania grass under omission of macronutrients in nutrient solution.

The plants were affected by the $S$ omission, causing visual symptoms and reduction of leaves and roots compared to the full solution treatment (Figure 1). The young and intermediate leaves showed chlorosis, similar results were found by Coelho et al. (2011). Chlorosis in young leaves is caused by low nutrient mobility in the plant (Prado, 2008a). Sulphur participates in the transport of electrons, photosynthesis, and respiration, in the catalytic sites of several enzymes and coenzymes (Epstein \& Bloom, 2006).

\section{Conclusions}

The omission of N, K, Ca and S limited the development of the Convert grass compared to the full solution treatment, decreasing the number of leaves, tillers, shoot height, root size and, dry mass production.

The omission of the respective nutrients modified the forage morphology, showing visual deficiency symptoms of each nutrient.

The descending order of onset of symptoms was $\mathrm{N}, \mathrm{Ca}, \mathrm{S}$, and $\mathrm{K}$.

\section{References}

Almeida, T.B.F., Prado, R.M., Correia, M.A.R., Puga, A.P., Barbosa, J.C. 2008. Avaliação nutricional da alface cultivada em soluções nutritivas suprimidas de macronutrientes. Revista Biotemas 24: 27-36.
Avalhães, C.C., Prado, R.M., Rozane, D.E., Romualdo, L.M., Correia, M.A.R. 2009. Omissão de macronutrientes no crescimento e no estado nutricional de capim - elefante (cv. Mott) cultivado em solução nutritiva. Scientia Agraria 10: $215-222$.

Argel, P. J., Miles, J. W., Guiot, J. D., Cuadrado, H., Lascano, C. E. 2007. Cultivar Mulato II (Brachiaria híbrida CIAT 36087): Gramínea de alta qualidade e produção forrageira, resistente às cigarrinhas e adaptada a solos tropicais ácidos. Boletim. Cali: CIAT, 2007. 22p.

Coelho, L.C., Kawamoto, L.S., Rodas, C.L.; Souza, G.A., Pinho, P.J., Carvalho, J.G. 2011. Caracterização de sintomas visuais, parâmetros de crescimento e desenvolvimento de Tagetes erecta sob deficiências nutricionais. Revista Agrarian 4: 113-122.

Duarte, C.F.D., Paiva, L.M., Fernandes, H.J., Prochera, D.L., Cassaro, L.H., Breure, M.F., Flores, L.S., Fernandes, R.L., Souza, E.R.C., Fleitas, A.C., Falcão, K.R.S. 2015. Capim-piatã adubado com fontes de fósforo de diferente solubilidade em água. Arquivo Brasileiro de Medicina Veterinária e Zootecnia 67: 315-318.

Epstein, E., Bloom, A. 2006. Nutrição mineral de plantas: Princípios e perspectivas. Planta, Londrina, Brasil, 403p.

Ferraz, J.B.S., Felício, P.E.D. 2010. Production systems an example from Brazil. Meat Science 84: 238243.

Ferreira, D. F. 2011. SISVAR: um programa para análises e ensino de estatística. Ciência e Agrotecnologia 6: 36-41.

Fonseca, I.M., Prado, R.M., Alves, A.U., Gondim, A.R.O. 2008. Crescimento e nutrição do sorgo (cv. BRS 304) em solução nutritiva. Revista de Biologia e Ciências da Terra 8:1 13-124.

Hoagland, D.R., Arnon, D.I. 1950. The water culture method for growing plants without soils. California Agricultural Experimental Station, Berkeley, USA. 32p.

Maia, J.T.L.S., Bonfim, F.P.G., Guanabens, R.E.M., Trentin, R., Martinez, H.E.P., Pereira, P.R.G., Fontes, P.C.R. 2014. Omissão de nutrientes em plantas de pinhão-manso cultivadas em solução nutritiva. Revista Ceres 61: 723-731.

Prado, R.M. 2008a. Manual de nutrição de plantas forrageiras. FUNEP, Jaboticabal, Brasil. 500p.

Prado, R. M. 2008b. Nutrição de plantas. Ed. UNESP, São Paulo, Brasil, 407p.

Prado, R.M., Franco, C.F., Puga, A.P. 2010. 
Deficiências de macronutrientes em plantas de soja cV. BRSMG 68 (Vencedora) cultivada em solução nutritiva. Comunicata Scientiae 1: 114119.

Prado, R.M., Hojo, R.H., Avalhães, C.C., Vale, D.W., Pimentel, U.V. 2011. Desempenho do capim-tanzânia cultivado em solução nutritiva com a omissão de macronutrientes. Scientia Agraria Paranaenis 10: 58-68.

Prado, R.M., Vidal, A.A. 2008. Efeitos da omissão de macronutrientes em solução nutritiva sobre o crescimento e a nutrição do milheto. Pesquisa Agropecuária Tropical 38: 208-214.

Rozane, D.E., Prado, R.M., Romualdo, L.M. 2008. Deficiências de macronutrientes no estado nutricional de aveia-preta cultivar comum. Revista Científica 36: 116-122.

Silva, E.B., Tanure, L.P.P., Santos, S.R., Resende Júnior, P.S. 2009. Sintomas visuais de deficiências nutricionais em pinhão-manso. Pesquisa Agropecuária Brasileira 44: 392-397.

Vale, D.W., Prado, R.M, Avalhães, C.C., Hojo, R.H. 2011. Omissão de macronutrientes na nutrição e no crescimento da cana-de-açúcar cultivada em solução nutritiva. Revista Brasileira de Ciências Agrárias 6:189-196.

Vieira, C.R., Weber, O.L.S., Scaramuzza, J.F., Costa, A.C., Souza, R.T. 2011. Descrição de sintomas visuais em função das deficiências de macronutrientes em mudas de cerejeira (Amburana acreana). Revista Floresta 41: 789 796. 